\title{
Neogenin expression is inversely associated with breast cancer grade in ex vivo
}

\author{
Wanying Xing ${ }^{1}$, Qiang $\mathrm{Li}^{2}$, Rangjuan $\mathrm{CaO}^{2}$ and Zheli $\mathrm{Xu}^{1 *}$
}

\begin{abstract}
Background: Neogenin is closely related to the human tumor suppressor gene deleted in colorectal cancer and plays a role in mammary morphogenesis. This study aimed to assess neogenin expression in breast cancer for any clinically significant association.

Methods: A total of 54 breast cancer patients who underwent modified radical mastectomy were enrolled for immunohistochemical and quantitative real-time PCR analysis of neogenin expression in their cancerous breast tissues in comparison to matching distant non-cancerous tissues.

Results: The data showed that the neogenin protein was either strongly or moderately expressed in the cytoplasm of the distant non-cancerous cells. In contrast, neogenin protein was either weakly or not expressed in the cytoplasm of 51/54 (94.4\%) breast cancer cells, among which 13 breast cancer cases did not express neogenin protein at all (13/54, 24.1\%). Similarly, levels of neogenin mRNA were significantly lower in breast cancer tissues than that of the matched distant non-cancerous tissues (51/54, 94.4\%). Neogenin expression was inversely associated with breast cancer grade; that is, grade III breast cancer expressed much less neogenin than grade $I-I I(P<0.05)$.
\end{abstract}

Conclusions: This study indicates that neogenin expression in breast cancer tissues is inversely associated with tumor grade.

Keywords: Neogenin, breast cancer, histological grading, predictive biomarkers

\section{Background}

Breast cancer is the most common cancer in women in both developed and developing countries [1]. In China, breast cancer accounts for $14.2 \%$ of all malignant tumors in Chinese women, while the percentage is $26.4 \%$ in the USA [2]. Despite advancements in early detection and treatment of breast cancer, breast cancer is still the leading cause of cancer-related death among women in the world $[3,4]$. Clinically, tumor stage, histological grade, and different tumor markers have been useful in evaluating and predicting breast cancer progression, treatment response, and prognosis [5]. Recently, researchers have tried to classify breast cancer based on the profile of differential gene expression to advance individualized treatment, and to help predict prognosis of the patients [6]. For example, breast cancer with estrogen receptor (ER)

\footnotetext{
* Correspondence: eryaoqi@126.com

${ }^{1}$ Department of Breast Surgery, China-Japan Union Hospital of Jilin University, Changchun 130033, China

Full list of author information is available at the end of the article
}

and progesterone receptor (PR) expression has been associated with sensitivity to endocrine therapy $[7,8]$, whereas human epidermal growth factor-2 (HER2)-overexpressed or HER-2-amplified breast cancer is resistant to endocrine therapy [9], but is more sensitive to trastuzumab [10,11]. ER, PR and HER-2-negative breast cancer (that is, triple negative breast cancer) [12] has the worst prognosis among all subtypes of breast cancer. To date, early detection is still key for survival of patients. Thus, identification and evaluation of novel tumor markers could help with early detection of breast cancer or the development of novel therapeutic targets for treatment of breast cancer patients.

Towards this end, our study focused on the protein neogenin, which is closely related to the human tumor suppressor gene deleted in colorectal cancer (DCC) [12] and which plays a role in mammary morphogenesis [13]. Neogenin has been shown to be expressed in a wide

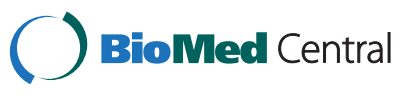

(c) 2014 Xing et al.; licensee BioMed Central Ltd. This is an Open Access article distributed under the terms of the Creative Commons Attribution License (http://creativecommons.org/licenses/by/4.0), which permits unrestricted use, distribution, and reproduction in any medium, provided the original work is properly credited. The Creative Commons Public Domain Dedication waiver (http://creativecommons.org/publicdomain/zero/1.0/) applies to the data made available in this article, unless otherwise stated. 
range of tissues in vertebrates, especially in sites where cells actively proliferate and migrate. Neogenin ligands include netrins and the family of repulsive guidance molecules (RGM) [14-16]. Neogenin has various functions dependent on its activation by different ligands; for example, after binding to netrin-1, neogenin can improve axon guidance by chemoattractively promoting cell migration and adhesion, whereas when binding RGM?, neogenin functions as a chemorepellant for cells [17]. Overall, the neogenin-ligand interaction can influence cell migration [17], tissue morphogenesis $[18,19]$, tumor growth $[20,21]$ and regulation of inflammation [22]. However, neogenin can induce apoptosis of certain types of cells when its ligands are absent. In the mammary gland, it has been shown that netrin-1-activated neogenin can stabilize multipotent progenitor cap cells during mammary gland morphogenesis [22,23], while another study showed that neogenin expression was inversely associated with mammary gland tumorigenesis [23]. However, in the original gene cloning and screening study [13], there was no alteration in neogenin expression observed in more than 50 types of human cancer cell lines, including breast cancer. In this study, we measured expression of neogenin mRNA and protein in breast cancer and compared this to expression in distant non-cancerous tissues in order to establish whether this receptor is clinically associated with breast cancer.

\section{Methods}

\section{Breast cancer tissue samples}

In this study, we recruited a total of 54 female primary breast cancer patients with a mean age of 51 years (range 30 to 75 years of age) who underwent modified radical mastectomy at the China-Japan Union Hospital of Jilin University between June 2012 and February 2013. None of these patients received preoperative chemo-, radiation-, or endocrine therapy. This study was approved by The Ethics Committee of Jilin University and all patients provided informed consent. Tissue specimens of breast cancer lesions and distant normal mammary glands were collected during the surgery, snap-frozen in liquid nitrogen, and stored at $-80^{\circ} \mathrm{C}$ before use. Tumors were diagnosed and classified according to the American Joint Committee on Cancer breast cancer TNM staging system [24] and the World Health Organization breast cancer histology and subtypes classifications [25].

\section{Immunohistochemical staining}

Formalin-fixed and paraffin-embedded tissue blocks were cut into $5 \mu \mathrm{m}$ thick tissue sections for immunohistochemical staining of ER, PR, HER2, Ki67, p53, and neogenin. Tissue sections were deparaffinized and re-hydrated routinely and then subjected to antigen retrieval by boiling in a pressure cooker in $10 \mathrm{mM}$ citrate buffer, $\mathrm{pH} 6.0$ at a pressure of $0.12 \mathrm{MPa}$ for 90 seconds. After treatment with $3 \% \mathrm{H}_{2} \mathrm{O}_{2}$ for 30 minutes, the sections were incubated with $20 \%$ normal serum for 50 minutes and then with the primary antibody overnight at $4^{\circ} \mathrm{C}$. The antibodies against ER, PR, HER2, Ki67, p53, and neogenin were obtained from Santa Cruz Biotechnology (Santa Cruz, CA, USA) and diluted according to the manufacturer's instructions. On the following day, the sections were washed with PBS thrice and then processed using an ultrasensitive TM S-P kit (Maixin Biotechnology, Fuzhou, China). After washes in PBS, the color reaction was developed using a 3,3'-diaminobenzidine kit (Maixin Biotechnology). The sections were counterstained with hematoxylin and covered with a coverslip.

The stained tissue sections were reviewed and scored independently by two pathologists (Drs Yang Hua and Chen Guiqiu). The proportion of tumor cells was scored as follows: none (no positive tumor cells), weak $(<10 \%$ positive tumor cells), moderate (10 to $50 \%$ positive tumor cells), and strong ( $>50 \%$ positive tumor cells). ER and PR positivity was defined as strong nuclear staining in at least $3 / 8$ of the tumor cells reviewed. HER $2 /$ neu positivity was defined as strong (3+) membranous staining in at least $10 \%$ of tumor cells, whereas scores of 0 to $2+$ were regarded as negative.

\section{RNA isolation, reverse transcription, and quantitative real-time PCR}

Total cellular RNA was isolated from frozen tissues using Trizol reagent (Invitrogen, Carlsbad, CA, USA) according to the manufacturer's protocol and was then incubated with DNase I (Invitrogen) to remove potentially contaminating genomic DNA. After purification, these RNA samples (5 $\mu \mathrm{g}$ each) were subjected to CDNA synthesis using an M-MLV reverse transcriptase kit (Promega, Madison, WI, USA). Next, these cDNA samples underwent quantitative PCR amplification using a StepOnePlus $^{\mathrm{Tm}}$ Real-Time PCR System (TaKaRa, Dalian, China). Primers for neogenin were 5'-ACA TGC TGC ACT GAT CAC CA-3' and 3'-TCA TAG GTG GGA GGT CCT GG-5'; for GAPDH were 5'-TGA TGA CAT CAA GAA GGT GGT GAA G-3' and 5'-TCC TTG GAG GCC ATG TGG GCC AT-3'. PCR conditions were set as follows: denaturation at $95^{\circ} \mathrm{C}$ for 5 minutes, followed by 40 cycles of $95^{\circ} \mathrm{C}$ for 5 seconds, $60^{\circ} \mathrm{C}$ for 10 seconds, and $72^{\circ} \mathrm{C}$ for 30 seconds, and an additional cycle at $85^{\circ} \mathrm{C}$ for 30 seconds to measure the SYBR Green fluorescence. Finally, the melting-curve was generated by slowly heating the $\mathrm{PCR}$ reactions to $95^{\circ} \mathrm{C}$ (by $0.3^{\circ} \mathrm{C}$ per cycle) while simultaneously measuring SYBR Green signal intensity. Relative mRNA expression of neogenin in all the tissue samples was normalized to that of GAPDH using the equation of $2^{-\Delta \Delta \mathrm{CT}}$. 


\section{Statistical analysis}

SPSS18.0 software (SPSS, Chicago, IL, USA) was used to statistically assess the $P$ value. Measurement data were analyzed by Student's $t$-test, while categorical data were analyzed by the chi-square test. Differences were considered statistically significant at $P<0.05$.

\section{Results}

Differential expression of neogenin in breast cancer and its distant non-cancerous tissues

We first detected expression of neogenin protein using immunohistochemical staining in 54 breast cancer and distant normal tissue samples. The results were scored as none, weak, moderate, and strong neogenin staining of epithelial cells according to the assessment of two independent pathologists. Neogenin protein was strongly or moderately expressed in the cytoplasm of the distant non-cancerous cells (Figure 1A). In contrast, neogenin protein was weakly or not stained in the cytoplasm of breast cancer cells (51/54, 94.4\%; Figure 1B), among which 13 breast cancer cases did not express neogenin protein at all. (13/54, 24.1\%; Figure 1C).

We then assessed neogenin mRNA expression in these tissue samples and found that the level of neogenin mRNA was significantly lower in breast cancer tissues than in the matched distant non-cancerous tissues (51/ 54, 94.4\%; Figure 1D).

\section{Association of neogenin expression with clinicopathological parameters from breast cancer patients}

We then associated the expression of neogenin protein with clinicopathological parameters from breast cancer patients (Table 1). The results show that neogenin expression is inversely associated with breast cancer grade; that is, grade III breast cancer expressed less neogenin than grade I-II (Figure 2A,B). Similar findings were observed with regard to neogenin mRNA expression $(P<0.05$; Figure $2 \mathrm{C}$ ). However, there was no association between neogenin expression and other clinicopathological parameters, such as tumor size, lymph node status, vascular invasion status, breast cancer subtype, TNM stage, and biomarker (ER, PR, HER-2, and Ki67).

\section{Discussion}

To date, neogenin expression has been shown to be downregulated in a variety of human cancers such as glioblastoma [26], colon cancer [27], prostate cancer [28], and breast cancer [24]. In the original neogenin cloning and screening study, Meyerhardt and colleagues [13] reported no alteration in neogenin expression in more than 50 different human cancer cell lines, including breast cancer cell lines. Later, Lee and colleagues [23] measured expression of neogenin in breast cancer cell lines and in eight matched breast cancer and adjacent non-cancerous tissues using Western blot, and in only breast cancer tissues by
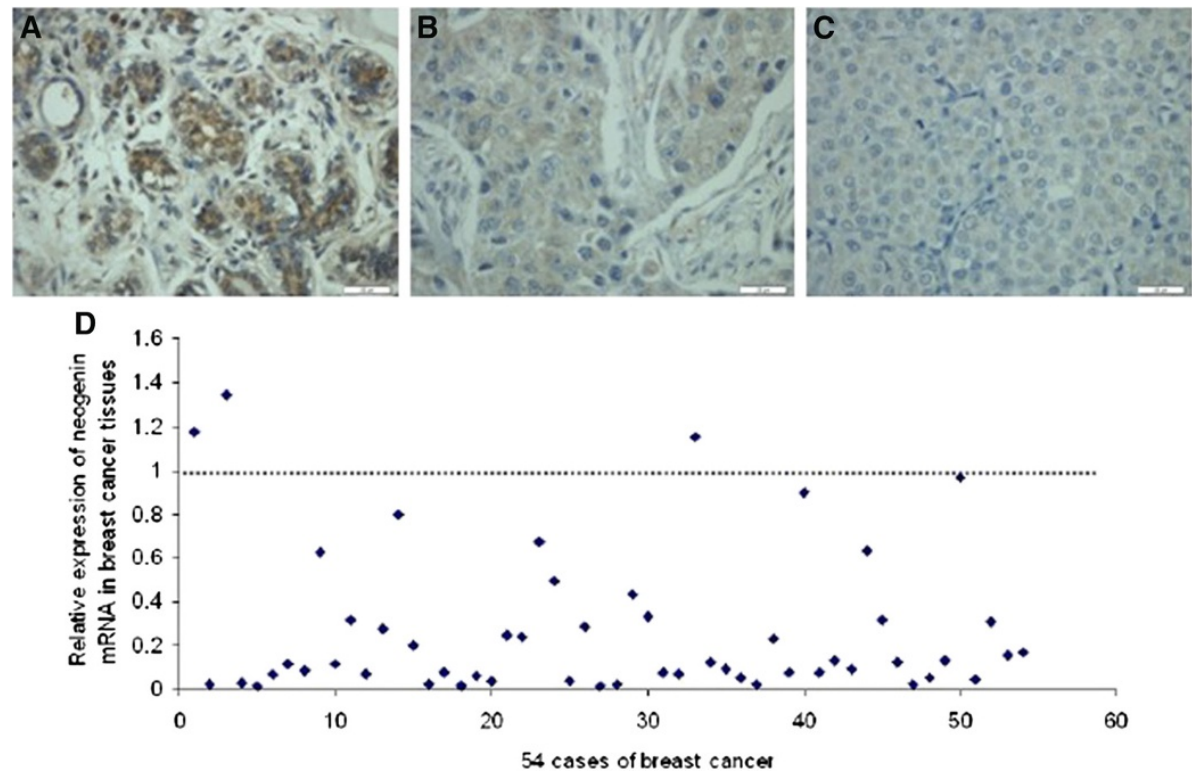

Figure 1 Differential expression of neogenin mRNA and protein in breast cancer and in matching distant non-malignant tissues.

(A) Immunohistochemistry; a representative case showing strong expression of neogenin protein in the cytoplasm of distant non-cancerous tissue. 200x magnification. (B) Immunohistochemistry; a representative case showing weak expression of neogenin in the cytoplasm of breast cancer tissues $(n=51)$. 200x magnification. (C) Immunohistochemistry; a representative case showing negative expression of neogenin protein in breast cancer tissue ( $n=13)$. (D) Quantitative real-time PCR; 51 out of 54 cases of breast cancer tissue showed a low level of neogenin mRNA compared to that of the matching distant non-cancerous tissue. The level of neogenin expressed in each distant non-cancerous tissue was normalized to 1 as a control. 
Table 1 Association between neogenin mRNA and protein levels and clinicopathological factors from breast cancer

\begin{tabular}{|c|c|c|c|c|}
\hline \multirow{2}{*}{$\begin{array}{l}\text { Clinicopathological } \\
\text { features }\end{array}$} & \multirow[t]{2}{*}{ Variable } & \multirow[b]{2}{*}{ N (\%) } & \multirow[b]{2}{*}{$\begin{array}{l}\text { Expression of neogenin } \\
\text { mRNA level mean } \pm \text { SD }\end{array}$} & \multirow[t]{2}{*}{$P$ value } \\
\hline & & & & \\
\hline \multirow[t]{2}{*}{ Age (years) } & $\geq 65$ & $4(7.4)$ & $0.042 \pm 0.035$ & 0.060 \\
\hline & $<65$ & $50(92.6)$ & $0.270 \pm 0.323$ & \\
\hline \multirow[t]{3}{*}{ Tumor size $(\mathrm{cm})$} & $\leq 2.00$ & $24(44.4)$ & $0.298 \pm 0.373$ & 0.959 \\
\hline & $2.01-5.00$ & $26(48.1)$ & $0.217 \pm 0.280$ & \\
\hline & $\geq 5.00$ & $4(7.4)$ & $0.372 \pm 0.412$ & \\
\hline \multirow[t]{3}{*}{ Histology grade } & । & $1(1.9)$ & $0.132 \pm 0$ & 0.032 \\
\hline & $\|$ & $29(53.7)$ & $0.330 \pm 0.343$ & \\
\hline & III & $24(44.4)$ & $0.192 \pm 0.313$ & \\
\hline \multirow[t]{4}{*}{ Stage } & 1 & $12(22.2)$ & $0.206 \pm 0.319$ & 0.818 \\
\hline & $\|$ & $19(35.2)$ & $0.292 \pm 0.322$ & \\
\hline & III & $14(25.9)$ & $0.254 \pm 0.357$ & \\
\hline & IV & $9(16.7)$ & $0.302 \pm 0.368$ & \\
\hline \multirow[t]{2}{*}{ Lymph node metastasis } & Yes & $35(64.8)$ & $0.320 \pm 0.356$ & 0.16 \\
\hline & No & 19 (35.2) & $0.164 \pm 0.257$ & \\
\hline \multirow[t]{2}{*}{ Vascular invasion } & Yes & $38(70.4)$ & $0.272 \pm 0.357$ & 0.755 \\
\hline & No & $16(29.6)$ & $0.247 \pm 0.268$ & \\
\hline \multirow[t]{4}{*}{ Subtype } & Luminal A & $13(24.1)$ & $0.407 \pm 0.400$ & 0.484 \\
\hline & Luminal B & $14(25.9)$ & $0.217 \pm 0.314$ & \\
\hline & H type & $14(25.9)$ & $0.199 \pm 0.236$ & \\
\hline & TNBC & $13(24.1)$ & $0.244 \pm 0.356$ & \\
\hline \multirow[t]{2}{*}{ ER } & + & $27(50)$ & $0.309 \pm 0.364$ & 0.387 \\
\hline & - & $27(50)$ & $0.221 \pm 0.295$ & \\
\hline \multirow[t]{2}{*}{ PR } & + & 21 (38.9) & $0.279 \pm 0.318$ & 0.908 \\
\hline & - & $33(61.1)$ & $0.256 \pm 0.344$ & \\
\hline \multirow[t]{2}{*}{ HER2 } & + & $21(38.9)$ & $0.239 \pm 0.290$ & 0.918 \\
\hline & - & $33(61.1)$ & $0.281 \pm 0.358$ & \\
\hline \multirow[t]{2}{*}{ Ki67 } & + & $39(72.2)$ & $0.256 \pm 0.333$ & 0.128 \\
\hline & - & $15(27.8)$ & $0.287 \pm 0.335$ & \\
\hline \multirow[t]{2}{*}{ p53 } & + & $21(38.9)$ & $0.308 \pm 0.371$ & 0.292 \\
\hline & - & $33(61.1)$ & $0.237 \pm 0.305$ & \\
\hline
\end{tabular}

ER, estrogen receptor, HER-2, human epidermal growth factor-2; PR, progesterone receptor; TNBC, triple negative breast cancer.

using tissue array. They found that neogenin expression was downregulated in both breast cancer cell lines as well as cancerous tissues and concluded that neogenin expression was inversely correlated with mammary carcinogenicity. Our current data support this and other previously published data [24] in that we have found an association between neogenin expression and breast cancer grade. We observed no neogenin expression in higher histological grade breast cancer compared to lower grade tumors, which is consistent with a study of glioma [22] where neogenin expression was inversely associated with histological grade of that cancer. Neogenin expression has been reported to be even lower in recurrent glioma cases compared to that of their primary tumors [22]. The histological grading system in breast cancer is based on differentiation of tumor cells, which is an important factor in predicting prognosis of breast cancer patients and tumor aggressiveness. Thus, we speculate that breast cancer with lower neogenin expression in the high histological grade might be more likely to recur and/or have a worse prognosis. However, the majority of our patients had grade II and III breast cancers which precluded precise evaluation of neogenin expression in grade I breast cancer. Future studies should recruit patients with this breast cancer grade to further confirm that neogenin expression is associated with breast cancer grade. 

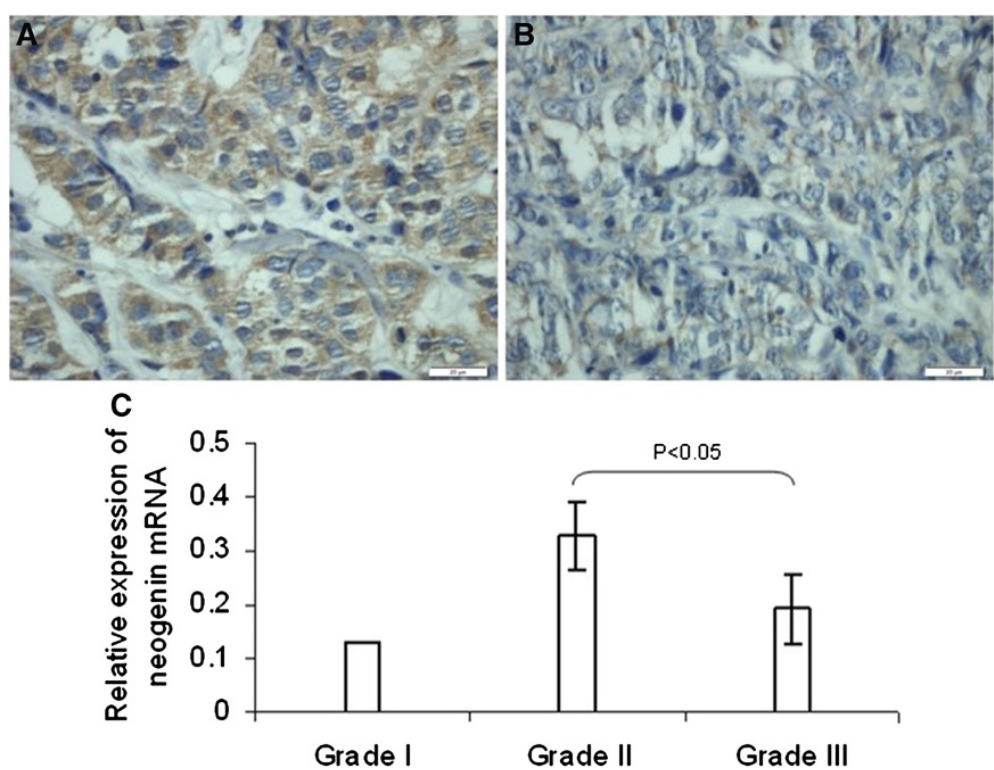

Figure 2 Association between neogenin expression and clinicopathological parameters from breast cancer patients. (A) Expression of neogenin in histology grade II breast cancer tissue $(n=29)$. 200x magnification. (B) Neogenin expression in histology grade III breast cancer tissue $(n=24)$. 200x magnification. (C) Expression of neogenin mRNA in different histological grades of breast cancer.

In the current study, we observed that level of neogenin expression was particularly low in the four patients who were 65 years or older. In parallel with our findings, Bondy and colleagues [29] also showed that minimum levels of neogenin appeared in older glioma patients with poor prognosis. As older patients frequently have systemic diseases after being diagnosed with breast cancer, treatment of older patients is conservative compared to younger ones [30]. Thus, neogenin should be further evaluated as a potential biomarker for older breast cancer. Based on our clinical experiences, malignancy of breast cancer is closely associated with tumor size, subtype, TNM stage, lymph node metastasis, vascular invasion, and expression of other biomarkers (such as ER, PR HER-2, and Ki67); however, we failed to find any statistical significance between neogenin expression and these prognostic factors. This indicates that neogenin expression and its functions warrant further investigation in breast cancer. A previous study showed that the function of neogenin in normal breast development is to guide cap cells and luminal cells into juxtaposition during the adolescent development period [22]. Although the combination of netrin-1 and neogenin plays a significant role during this process, the role of neogenin in breast cancer remains to be determined. It has previously been shown that neogenin might function as an independent receptor in breast cancer to suppress tumor development [24]. When neogenin levels are downregulated, neogenin-induced apoptosis could be interrupted which could, in turn, lead to cancer development $[20,31]$. Similarly, other studies suggest that neogenin could induce chemoattraction or chemorepulsion after binding to ligands such as netrin-1 and RGM to influence tumor cell migration and invasion [21,32]. In addition, we have shown in the current study that neogenin expression is only marginally associated with lymph node metastasis of breast cancer.

\section{Conclusions}

As such, we hypothesize that the level of neogenin expression could be altered during tumorigenesis and that a lack of neogenin expression could promote tumorigenesis early in the process but that, following tumor formation, certain tumor cells may re-express neogenin protein to promote tumor cell migration and metastasis. However, further studies are needed to clarify the function of neogenin as well as the cause of lost neogenin expression in breast cancer before neogenin can be established as a biomarker for breast cancer diagnosis.

\section{Consent}

Written informed consent was obtained from the patient for the publication of this report and any accompanying images.

\section{Abbreviations}

DCC: deleted in colorectal cancer; ER: estrogen receptor; HER-2: human epidermal growth factor-2; PBS: phosphate-buffered saline; PCR: polymerase chain reaction; PR: progesterone receptor; RGM: repulsive guidance molecules.

\section{Competing interests}

The authors declare that they have no competing interests. 


\section{Authors' contributions}

ZX and WX conceived and designed the study. QL revised the manuscript. $W X$ and RC performed the experiments and drafted the manuscript. WX and QL performed patient collection, clinical data interpretation, and statistical analysis. All authors read and approved the final manuscript.

\section{Acknowledgements}

This study was supported in part by grants from Wu Jieping Medical Foundation (\#320.6750.12280), the Graduated Innovation Fund of Jilin University and the Scientific Research Foundation from Northeast Normal University (12SSXT134)

\section{Author details}

${ }^{1}$ Department of Breast Surgery, China-Japan Union Hospital of Jilin University, Changchun 130033, China. ${ }^{2}$ Department of Hand Surgery, China-Japan Union Hospital of Jilin University, Changchun 130033, China.

Received: 29 May 2014 Accepted: 2 October 2014 Published: 22 November 2014

\section{References}

1. Dey S, Soliman AS: Cancer in the global health era: opportunities for the Middle East and Asia. Asia Pac J Public Health 2010, 22:75S-82S.

2. Wang YC, Wei LJ, Liu JT, Li SX, Wang QS: Comparison of cancer incidence between China and the USA. Cancer Biol Med 2012, 9:128-132.

3. Jemal A, Siegel R, Ward E, Hao Y, Xu J, Thun MJ: Cancer statistics, 2009. CA Cancer J Clin 2009, 59:225-249.

4. La Vecchia C, Bosetti C, Lucchini F, Bertuccio P, Negri E, Boyle P, Levi F: Cancer mortality in Europe, 2000-2004, and an overview of trends since 1975. Ann Oncol 2010, 21:1323-1360.

5. Chung C, Christianson M: Predictive and prognostic biomarkers with therapeutic targets in breast, colorectal, and non-small cell lung cancers: a systemic review of current development, evidence, and recommendation. J Oncol Pharm Pract 2014, 20:11-28.

6. Pathmanathan N, Balleine RL: Ki67 and proliferation in breast cancer. J Clin Pathol 2013, 66:512-516.

7. Harvey JM, Clark GM, Osborne CK, Allred DC: Estrogen receptor status by immunohistochemistry is superior to the ligand-binding assay for predicting response to adjuvant endocrine therapy in breast cancer. J Clin Oncol 1999, 17:1474-1481.

8. Mohsin SK, Weiss H, Havighurst T, Clark GM, Berardo M, Roanh le D, To TV, Qian Z, Love RR, Allred DC: Progesterone receptor by immunohistochemistry and clinical outcome in breast cancer: a validation study. Mod Pathol 2004, 17:1545-1554

9. Dowsett M, Cuzick J, Ingle J, Coates A, Forbes J, Bliss J, Buyse M, Baum M, Buzdar A, Colleoni M: Meta-analysis of breast cancer outcomes in adjuvant trials of aromatase inhibitors versus tamoxifen. J Clin Oncol 2010, 28:509-518.

10. Ross JS, Linette GP, Stec J, Clark E, Ayers M, Leschly N, Symmans WF, Hortobagyi GN, Pusztai L: Breast cancer biomarkers and molecular medicine: part II. Expert Rev Mol Diagn 2004, 4:169-188.

11. Allred DC: Issues and updates: evaluating estrogen receptor-a, progesterone receptor, and HER2 in breast cancer. Modern Pathology 2010, 23:S52-S59.

12. Stagg J, Allard B: Immunotherapeutic approaches in triple-negative breast cancer: latest research and clinical prospects. Ther Adv Med Oncol 2013, 5:169-181

13. Meyerhardt JA, Look AT, Bigner SH, Fearon ER: Identification and characterization of neogenin, a DCC-related gene. Oncogene 1997, 14:1129-1136

14. Rajagopalan S, Deitinghoff L, Davis D, Conrad S, Skutella T, Chedotal A, Mueller BK, Strittmatter SM: Neogenin mediates the action of repulsive guidance molecule. Nat Cell Biol 2004, 6:756-762

15. Matsunaga E, Tauszig-Delamasure S, Monnier PP, Mueller BK, Strittmatter SM, Mehlen $\mathrm{P}$, Chédotal A: RGM and its receptor neogenin regulate neuronal survival. Nat Cell Biol 2004, 6:749-755.

16. De Vries $\mathrm{M}$, Cooper HM: Emerging roles for neogenin and its ligands in CNS development. J Neurochem 2008, 106:1483-1492.

17. Hebrok M, Reichardt LF: Brain meets pancreas: netrin, an axon guidance molecule, controls epithelial cell migration. Trends Cell Biol 2004, 14:153-155.
18. Liu Y, Stein E, Oliver T, Li Y, Brunken WJ, Koch M, Tessier-Lavigne M, Hogan BLM: Novel role for netrins in regulating epithelial behavior during lung branching morphogenesis. Curr Biol 2004, 14:897-905.

19. Lu X, Le Noble F, Yuan L, Jiang Q, De Lafarge B, Sugiyama D, Bréant C, Claes $F$, De Smet F, Thomas J-L: The netrin receptor UNC5B mediates guidance events controlling morphogenesis of the vascular system. Nature 2004, 432:179-186.

20. Arakawa H: Netrin-1 and its receptors in tumorigenesis. Nat Rev Cancer 2004, 4:978-987.

21. Fitamant J, Guenebeaud C, Coissieux M-M, Guix C, Treilleux I, Scoazec J-Y, Bachelot T, Bernet A, Mehlen P: Netrin-1 expression confers a selective advantage for tumor cell survival in metastatic breast cancer. PNAS 2008, 105:4850-4855

22. Ly NP, Komatsuzaki K, Fraser IP, Tseng AA, Prodhan P, Moore K, Kinane TB: Netrin-1 inhibits leukocyte migration in vitro and in vivo. Science Signaling 2005, 102:14729.

23. Lee JE, Kim HJ, Bae JY, Kim SW, Park J-S, Shin HJ, Han W, Kim S-W, Kang K-S, Noh D-Y: Neogenin expression may be inversely correlated to the tumorigenicity of human breast cancer. BMC Cancer 2005, 5:154.

24. Benson JR, Weaver DL, Mittra I, Hayashi M: The TNM staging system and breast cancer. Lancet Oncol 2003, 4:56-60.

25. Frank GA, Danilova NV, Andreeva I, Nefedova NA: [WHO classification of tumors of the breast, 2012]. Arkh Patol 2013, 75:53-63.

26. Wu X, Li Y, Wan X, Kayira TM, Cao R, Ju X, Zhu X, Zhao G: Down-regulation of neogenin accelerated glioma progression through promoter methylation and its overexpression in SHG-44 induced apoptosis. PLoS One 2012, 7:e38074.

27. Li VS, Yuen ST, Chan TL, Yan HH, Law WL, Yeung BH, Chan AS, Tsui WY, So S, Chen X, Leung SY: Frequent inactivation of axon guidance molecule RGMA in human colon cancer through genetic and epigenetic mechanisms. Gastroenterology 2009, 137:176-187.

28. Latil A, Chene L, Cochant-Priollet B, Mangin P, Fournier G, Berthon P, Cussenot $\mathrm{O}$ : Quantification of expression of netrins, slits and their receptors in human prostate tumors. Int J Cancer 2003, 103:306-315.

29. Bondy ML, Scheurer ME, Malmer B, Barnholtz-Sloan JS, Davis FG, II'Yasova D, Kruchko C, McCarthy BJ, Rajaraman P, Schwartzbaum JA: Brain tumor epidemiology: consensus from the Brain Tumor Epidemiology Consortium. Cancer 2008, 113:1953-1968.

30. Lavelle K, Moran A, Howell A, Bundred N, Campbell M, Todd C: Older women with operable breast cancer are less likely to have surgery. Br J Surg 2007, 94:1209-1215.

31. Bernet A, Mehlen P: Dependence receptors: when apoptosis controls tumor progression. Bull Cancer 2007, 94:10012-10017.

32. Strizzi L, Bianco C, Raafat A, Abdallah W, Chang C, Raafat D, Hirota M, Hamada S, Sun Y, Normanno N, Callahan R, Hinck L, Salomon D: Netrin-1 regulates invasion and migration of mouse mammary epithelial cells overexpressing Cripto-1 in vitro and in vivo. J Cell Sci 2005, 118(Pt 20):4633-43.

doi:10.1186/1477-7819-12-352

Cite this article as: Xing et al:: Neogenin expression is inversely associated with breast cancer grade in ex vivo. World Journal of Surgical Oncology 2014 12:352.

\section{Submit your next manuscript to BioMed Central and take full advantage of:}

- Convenient online submission

- Thorough peer review

- No space constraints or color figure charges

- Immediate publication on acceptance

- Inclusion in PubMed, CAS, Scopus and Google Scholar

- Research which is freely available for redistribution 